\title{
Implications of the Digital Economy on Merger Control in Pakistan and China: Policy Implications for Pakistan
}

\author{
Yuhui Wang ${ }^{1} \&$ Shahzada Aamir Mushtaq ${ }^{1}$ \\ ${ }^{1}$ School of Law and Economics Zhengzhou University, Henan, People's Republic of China. \\ Correspondence: Yuhui Wang, 100 Kexue Ave, Zhongyuan Qu, Zhengzhou Shi, Henan Sheng, China. E-mail: \\ 550805852@qq.com
}

Received: September 5, 2021

Accepted: November 28, 2021

Online Published: December 12, 2021

doi:10.5539/jpl.v15n1p40

URL: https://doi.org/10.5539/jpl.v15n1p40

The project is supported by program for innovative Research team (in science and technology) by University of Henan Province (211RTSTHN012).

\begin{abstract}
The rise of the digital economy has challenged the foundation of competition law frameworks the world over. Today, the antitrust doctrine finds itself confronting a new economy; an econo-my wherein data acts as a currency, markets are without prices, market collisions are based on algorithms, and the market is 'infinite'. Several jurisdictions such as Germany, Austria, and China have developed new regulations or amended existing legislations to confront the chal-lenges presented by the digital economy. A dearth of theoretical and empirical literature has evaluated whether digital markets are so fundamentally different as to require a different set of rules. Of specific interest to this paper is whether current competition rules are sufficient to deal with mergers and acquisitions (M\&As) in digital markets. This paper assesses M\&A regulations in China and Pakistan in light of the new digital economy. Expert interviews were conducted using semi-structured interviews to investigate the comparisons between Pakistan's and China's merger control regimes. The findings indicate that China's merger control regulations are better adopted for the digital economy than Pakistani's. It also sets out the policy implications for competition policy makers in Pakistan.
\end{abstract}

Keywords: digital economy, online platforms, Merger and Acquisitions, network effects, Anti-trust law, sustainable development

\section{Introduction}

The last two decades have witnessed the emergence of a plethora of digital platforms, which have occasioned rapid and profound technological developments. Platform-based businesses such as Facebook, Amazon, e-Bay, Google, and Alibaba use data-driven busi-ness models that bring together a set of parties to interact and exchange information, goods, and services over the internet. The inherent nature and design of data-driven busi-nesses have presented challenges for the traditional antitrust law framework (Atanasian, 2018). Current antitrust thinking and enforcement are grounded in the economic models of monopolistic and oligopolistic market structures, which are inevitably and fully con-strained by the laws of demand and decreasing returns to scale (Chirita, 2019). Platformization has necessitated a revision of the conventional antitrust instruments to accommo-date the digital economic postulates (Gal \& Cheng, 2016).

One of the key aspects of digital platforms, and which poses an immediate challenge to competition law, is multisidedness. Online platforms bring together two sets of users interacting with one another via the platform (Crémer et al., 2019). It is, therefore, possible to offer one service for free and derive revenues from the other side of the platform (Crémer et al., 2019). The driver of digital platforms is to explore new ways of attracting users who can give up personal data in exchange for a free service (Dessemond, 2020). Although users do not pay a monetary consideration for the use of platform services, they indirectly con-tribute to the service's monetization. Thus, in contrast to traditional markets where ser-vices are monetized on the consumer side, price does not play a decisive role in the digital economy (Lundqvist, 2019). Furthermore, since consumers do not pay directly for the use of a platform's services, they have little incentive to switch (Chirita, 2019). This means that unlike in traditional markets where new entrants can undercut on price to secure a cus-tomer base, start-ups in digital markets can only 
attract customers through demonstrably more innovative or better quality products, services, or features.

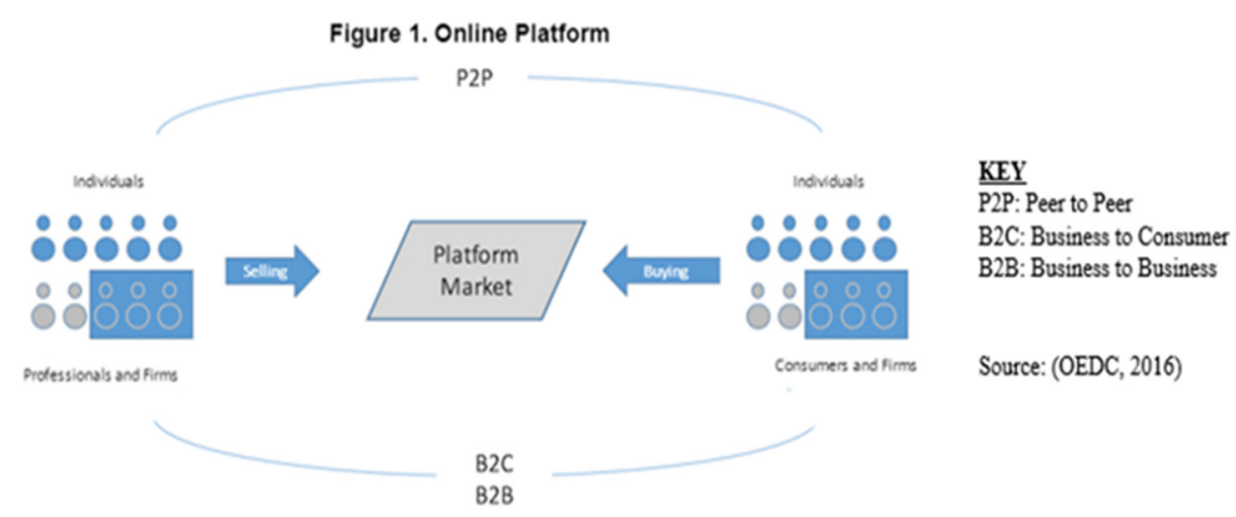

Figure 1. Graph of online transactions and network effects

Digital platforms are two-sided, a characteristic which confers them network effects - which is the effect a user of a product or service has on the value of that product to other consumers (Newman, 2018). The utility of using a digital platform is directly proportional to the number of users - the greater the user base, the greater the scope for attracting ad-vertisements and monetizing the services. The acquisition of network effects and the con-trol of data generate economies of scope and scale, consequently creating significant mar-ket entry barriers (Newman, 2018). For example, compared to Google, new entrants into the 'online search' market do not have the advantage of big data that they can use to im-prove their search algorithms. For newcomers, creating a platform that can attract consid-erable traffic from both the demand and supply sides is a huge challenge (Maher et al., 2016). Additionally, even when start-ups successfully navigate these challenges, they still face competitive pressure and may soon be acquired by dominant players (Newman, 2018).

The neoclassical approach to doing business - in which the goal of a private compa-ny is to maximize profits, has been challenged by digital platforms. In digital markets, growth in the short to medium term is prioritized over profits (Lundqvist, 2019). Digital companies seek to maximize the number of users on their platform regardless of whether they are making a loss. Additionally, the companies are rapidly expanding into related business areas to access more user data (Lundqvist, 2019). For instance, Google does not charge mobile phone manufacturers for using the Android operating system but uses this model as a leeway to collect more user data.

The features and dynamics of digital markets are not new to regulators. Competition authorities, for example, have long dealt with the advertising model of generating revenue which was brought to the fore by traditional media such as television (Maher et al., 2016). However, the combination of several or all of the features of digital platforms raises a challenge from a merger control perspective. In a market where the possibility of high concentration is high (due to access to huge amounts of data and network effects), incor-rectly clearing a merger could have severe consequences (UNCTAD, 2019).

\section{Merger Control in Digital Markets}

In recent years, the world has witnessed mega-mergers and acquisitions worth billions of dollars. Much of the merger activity has taken place in digital markets. The most notable acquisitions include the acquisition of Double Click by Google (2008), acquisition of Ya-hoo (2010), Skype (2011), and LinkedIn (2016) by Microsoft, Facebook-WhatsApp merger (2014), and the Sanofi-Google merger (2016) (Argentesi et al., 2020). Tech giants in the dig-ital economy such as Google, Facebook, Amazon, Uber, and Alibaba have been and con-tinue to be aggressively involved in M\&A, as shown in Figure 2. 


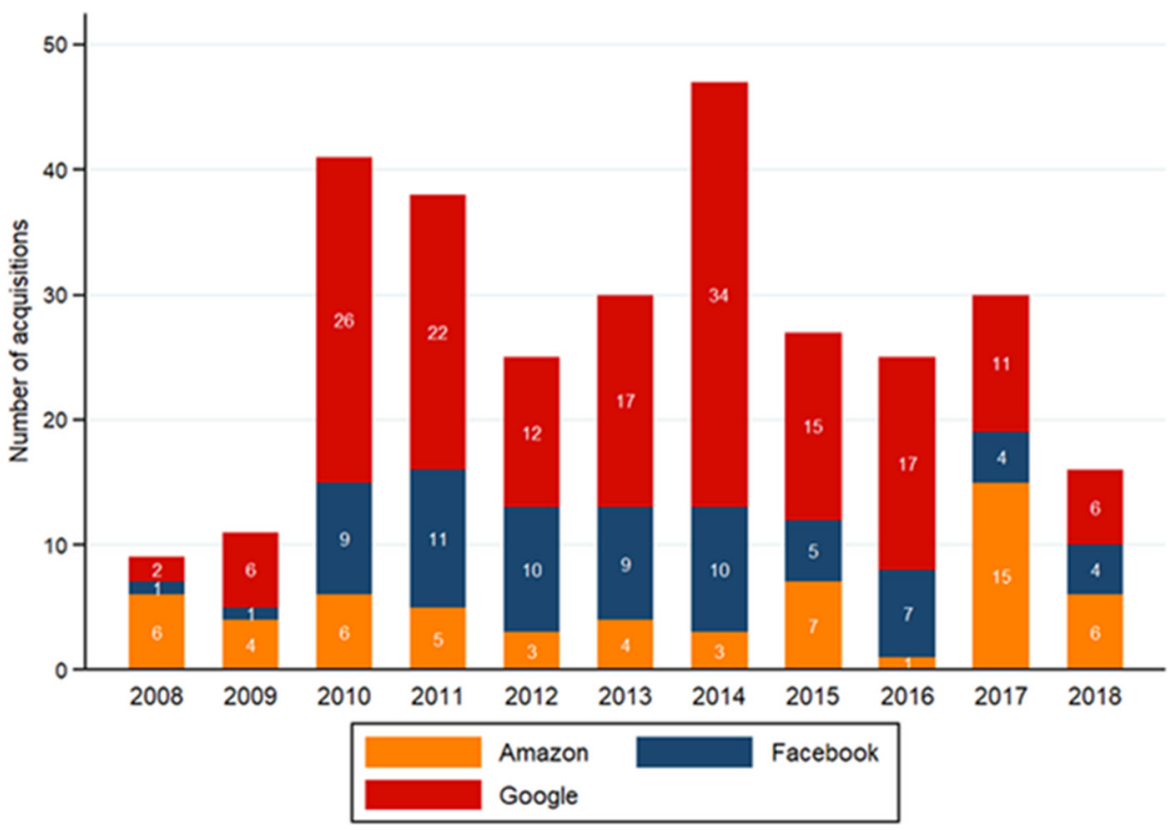

Figure 2. Google, Amazon, and Facebook Acquisitions (2008 - 2018)

[Source: Argentesi et al., 2020]

Big tech companies target and acquire innovative start-ups to improve their ecosystem. Although digital M\&As have the potential to produce benefits for consumers through in-creased innovation, competition authorities are concerned that such M\&As have an-ti-competitive effects since the target is prevented from ever becoming a competitive threat to the acquiring company (Wirth \& Parr, 2020). In digital markets, the competitive threat of start-ups is significant as it fosters innovation (dynamic innovation) and serves to disci-pline the market behavior of incumbents (static efficiency) (Argentesi et al., 2020). Incum-bents may also use M\&As as a tool to cement their market dominance, making it consid-erably difficult for new companies to enter the market (Argentesi et al., 2020).

The acquisition of young companies is problematic for competition policy since the transactions do not meet the turnover thresholds that trigger merger control, preventing competition authorities from examining them (Yüksel et al., 2020). Jurisdictional thresh-olds based on turnover are often too high to capture mergers involving start-up compa-nies. However, if too low revenue thresholds are introduced, authorities would be spend-ing a vast amount of time evaluating irrelevant transactions resulting in inefficiencies and resource problems (Newman, 2018). A possible remedy to this problem is the adoption of alternative approaches to revenue thresholds such as transaction value thresholds in or-der to capture transactions involving companies with low revenues but with high poten-tial impact (Newman, 2018). Some competition authorities, such as Bundeskartellamt (Germany), have established sector-specific merger review policies for the digital markets (WEF, 2019).

Defining the market for digital platforms is a challenging task for regulatory authorities. Traditionally, many competition bodies around the world define the relevant market us-ing the SSNIP (Small but Significant NonTransitory Increase in Price) test (Chirita, 2019). However, digital platforms are multi-sided markets where prices are zero on one side, and prices are set to maximize profits on the other side. There is a lack of a single price to which SSNIP can be applied. Additionally, indirect network effects may amplify the im-pact of SSNIP on one set of customers (Chirita, 2019).

Mergers in the digital sector often entail transactions with horizontal overlaps creating unilateral effects (Lundqvist, 2019). Dominant tech companies acquire small firms that are active within the same market and closely compete with the acquirer's products. While it may not plainly appear that the target is directly competing with the acquirer, data ag-gregation and greater consumer attention may increase the acquirer's market power (Lundqvist, 2019). For example, in the Facebook/WhatsApp and Facebook/Instagram mergers, competition concerns were not raised as it appeared that both targets were providing differentiated services from social networking. WhatsApp is a communications app for smartphones, and Instagram is a mobile-based photo app. While both targets' services are 
different from those offered by Facebook, the companies are competing for the same thing - consumer data and customer attention. Thus, the resultant market power of the merged entity derived from the combination of previously two independent datasets should be sufficiently evaluated before dismissing the theory of harm (McKenzie \& Lee, 2011).

The challenges posed by digital platforms from a merger control perspective do not imply that the current instruments are inapplicable and no longer valid (Yüksel et al., 2020). However, competition authorities should apply flexibility in the assessment of digital mergers to consider all the dynamics of parties in the digital economy in relation to actual and potential competition ex-post (Yüksel et al., 2020).

\section{The Context of Pakistan}

For emerging markets such as Pakistan, public discourse on digital platforms is long overdue. Pakistan technology ecosystem has been gradually gaining momentum, a phe-nomenon attributable to a pool of tech talent and a large digitally-savvy population (Partington, 2020). Since 2010, 720 start-ups have been created, 70 percent of which are still in operation. More than 100 of these startups have successfully raised funding (Rob-inson, 2020). From 2015 -2020, 122 deals involving Pakistani start-ups and worth $\$ 178$ million were completed. There were also 19 deals whose amounts were not disclosed, bringing the total to 141 start-ups (Robinson, 2020). Some of the most funded innovative start-ups in Pakistan include (Lilani, 2021):

(i) Zameen.com - Zameen.com was founded in 2006 as an online property portal that allows customers to buy, invest, and sell properties in Pakistan's major cities. The com-pany has raised a total funding of \$29 million in seed, Series' A, B, and C from Vostok New Ventures (\$9 million), and Frontier Digital Ventures (\$20 million). The company is currently valued at approximately $\$ 80$ million.

(ii) Airlift - An mobile-based transportation service provider that enables commuters to book luxury buses. Since its founding in 2018, the company has raised \$24.2 million in seed, Series A, and Series A1 from several venture capitalists including First Round Capi-tal (U.S.), Indus Valley Capital (Pakistan), Gobi Partners (China), Fatima Ventures (Paki-stan), True Sight Ventures (UK)), Shorooq Partners (UAE), and RT Ventures (UK).

(iii) Finja - Founded in 2015, Finja is a provider of B2B and B2C payment solutions. The company has innovated some of the most renowned online payment solutions in Paki-stan including Payroll Plus and SimSim. In 2016, Finja secured \$1 million seed capital from Vostok Emerging Finance (Sweden). It has also raised \$1.5 million in Series A, \$3 million in convertible notes, and \$9 million Series A1 funding from Vostok Emerging Fi-nance, ICU Ventures (Ukraine), BeeNext (Singapore), Gray MacKenzie Engineering Ser-vices (UAE), and Quona Capital (U.S.).

(iv) Bykea - A logistics and on-demand delivery start-up founded in 2016. The company has raised a total of \$18.7 million in seed, Series A, and Series B funding from Sarmayacar (Pakistan), Middle East Venture Partners (UAE), and MEVP (Lebanon).

(v) Inov8 - Inov8 was founded in 2004 as an online payment solutions provider for the mobile banking, ecommerce, and branchless banking sectors. The company has raised over \$5.4 million in Series A from Nahyan bin Mubarak Al Nahyan, an angel investor based in Dubai.

(vi) Cheetay - Cheetay is an on-demand logistics and transport company founded in 2016. Cheetay has secured \$9.7 million from U.S. investors in seed, Series A, and Series A1 funding.

(vii) Rozee.pk - Founded in 2005, Rozee.pk is one of the most renowned job sites in Paki-stan linking job seekers with employment opportunities. The company has raised \$8.5 million from Draper Fisher Jurvetson (U.S.), Vostok New Ventures, ePlanet Capital (U.S.), and Piton Capital (U.K.).

(viii) Oladoc - a health-based tech startup that enables customers to book a medical health professional. Oladoc has secured over $\$ 1.2$ million.

(ix) Sastaticket - The company provides online travel agency services covering hotel, holiday, and air travel packages. Founded in 2016, Sastaticket has raised \$1.5 million from Gobi Partners.

(x) Other successful tech start-ups include Tez Financial Services (mobile-based finan-cial services provider targeting Pakistan's unbanked population), Well.pk (e-commerce), Tellotalk (a homegrown messaging app), PriceOye (e-commerce aggregator), Queno (an education technology start-up offering ERP (Enterprise Resource Planning) software to Pakistani schools), Medznmore (online pharmacy), Bazaar (B2B wholesale marketplace), Truck It In (trucking marketplace), KTown Rooms (online hotel booking), SadaPay (finan-cial technology), and EdKasa (examination preparation app for high school students).

These start-ups represent hundreds of new tech companies that are springing up in Paki-stan. In fact, the digital 
wave in the country referring to Pakistan as the "Next big Asian market for tech start-ups" (Partington, 2020). Several incubators and accelerators have been established in Pakistan in the last few years. They include PlanX, Technology Incu-bation Center, the Nest i/o, i2i, LUMS Center for Entrepreneurship, Basecamp, DotZero, and the Founder Institute (Khan, 2021). The wave of digital innovation has also been en-hanced by the Pakistani government's commitment to create an enabling environment for tech start-ups. In December 2019, the government launched the "Digital Pakistani" initia-tive whose objective is to increase technology access and increase digital awareness among the Pakistani population (Karachi Chamber of Commerce and Industry, 2021). The Pakistani government has also established "PakImpactInvest", an investment platform providing early-stage and growth funding to tech and social impact start-ups (Kahn, 2021).

With Pakistan's technology ecosystem is rapidly gaining momentum, mergers and acqui-sitions in the country's digital market are inevitable. In 2018, Alibaba acquired Daraz, an online retailer for an undisclosed amount (Nicola, 2018). Also in 2019, Uber acquired the Pakistani-founded on-demand ride-hailing app, Careem, for $\$ 3.1$ billion (Uber, 2020). As Pakistan's technology startup' industry grows, M\&A activity is expected to increase. The Pakistani competition regulator, the Competition Commission of Pakistan (CCP) must re-examine the antitrust policies it has previously applied to traditional mergers to ade-quately address the issues raised by mergers in the domestic digital market.

\section{Merger Review in Pakistan}

The Pakistani merger control regime has seen significant developments following the im-plementation of the Competition Act 2010 (the Competition Act or the Act) vide the Com-petition Ordinance 2007 (2007 Regulations) (Daudpota, 2019). The Competition Act is the primary statute for merger regulation in Pakistan and is supplemented by the 2007 regu-lations and the companies Court Rules 1997 (the 1997 Rules) (Daudpota, 2019). The Competition Commission of Pakistan (CCP) and the Securities and Exchange Commis-sion of Pakistan (SECP) are the primary authorities that approve or sanction mergers in Pakistan (UNCTAD, 2013). The High Court also plays a significant role in granting or re-jecting merger applications in accordance with the Pakistani company laws.

Section 2(1)(h) of the Competition Act defines a merger as "the merger, acquisition, amal-gamation, combination or joining of two or more undertakings or part thereof into an ex-isting undertaking or to form a new undertaking" (Competition Act, 2010). The law re-quires that intended mergers that meet the notification criteria as spelt out in regulation 4 of the 2007 Regulations be notified to the Commission. Mergers or acquisitions that would create or strengthen the market dominance of the merged entity, thereby lessening compe-tition are expressly prohibited (CCP, 2016). The Commission has the authority to prevent mergers with potential anti-competitive effects. It can also set conditions or require divest-itures (CCP, 2016). Vertical and horizontal mergers are, however, not distinguished under the law (Wilson, 2011).

In addition to enforcing Regulation 4, the CCP also enforces Section 11 of the 2007 Regula-tions. Section 11 makes it mandatory for merger transactions above the thresholds relating to the size of the transaction and the parties to the proposed merger to be notified (Khan et al., 2017). According to Article 4(2), undertakings intending to merge should make an ap-plication for clearance if the gross asset value or annual turnover is higher than 300 mil-lion rupees, or where the total turnover or stock value of both the acquirer is 1 billion ru-pees or higher (Khan et al., 2017).

For the "first phase" review, the Commission is expected to issue a determination within 30 days after notification (Daudpota, 2019). Failure to do so implies that there is no objec-tion to the proposed merger. Depending on the size of the merging parties, a filing fee is payable upon notification. Moreover, under the law, no restrictive time limits are set for applicants. Parties to an intended transaction can make an application as soon they sign a letter of intent to merge that need not be binding, or agree in principle to enter into the merger transaction (Daudpota, 2019).

If a case proceeds to the "second phase review", the Commission is expected to issue a de-cision within 90 days (Khan et al., 2017). Similarly, if the Commission fails to render a de-termination on the proposed transaction within the 90-day time-frame, it means that it has objection to the proposed transaction. If the Commission established that the transac-tion is likely to lessen competition after the second phase review, it may still approve the merger if it is manifested that (Daudpota, 2019): (a) the transaction substantially increases the efficiency of the business, (b) a less restrictive means of competition cannot reasonably achieve such efficiency, (c) the efficiency achieved from the merger is greater than the neg-ative impact of the lessening of competition or its absence thereof and (d) the business is experiencing imminent or actual financial failure and the merger is the least an-ti-competitive resort to recover its assets. 
If the CCP determines from the transaction review that it does meet the qualification crite-ria for approval, it may (Wilson, 2011) (a) disallow the merger (b) authorize the merger subject to certain predetermined conditions, and (c) approve the transaction subject to the undertaking entering into certain agreements as specified by the CCP. Section 31 of the Competition Act empowers the CCP to review the order for approval of a merger for the conditional decisions with one year (Competition Commission of Pakistan, 2016). The Commission may conduct such a review upon the request from the parties or on its own should it determine that market circumstances or of the undertakings have changed. Since such a review may lead to legal uncertainty, such a review must be cum grano salis and be reasonably grounded and substantiated (Daudpota, 2019).

The remedies available to the CCP include remedies that (UNCTAD, 2013) (a) may restore all or part of the market structure such as prohibition of an intended transaction, divest-ment of a completed merger, and partial divestment, (b) remedies that may enhance com-petition such as dismantling exclusive distribution agreements, doing away with clauses in customer agreements that restrict competition, and requiring access to core facilities or inputs, and (c) remedies intended at limiting or excluding the possibility of the merged entity taking advantage of the increased market power resulting from the merger such as a requirement to increase price transparency, obligation to refrain from limiting entry of new competitors, or commitment to non-discriminatory behavior. The remedies taken by the Commission depend on the circumstances and facts of the case.

In accordance with Section 38 of the Competition Act, the Commission has the power to direct any entity to pay a sum specified by the Commission if it is determined that the en-tity is engaging in prohibited activities (Competition Commission of Pakistan, 2016). Such penalties shall be imposed through an order. Further, the Act also states that failure to comply with the Commission's orders constitutes a criminal offense, punishable with a fine of a sum not exceeding 25 million rupees, one-year imprisonment, or both (CCP, 2016).

As earlier mentioned, Pakistan has made significant steps in terms of competition law and regulation. The era of temporary presidential ordinances serving as the sole regulato-ry mechanism is long gone. The current model and structure of competition law and en-forcement is in conformity with international best practices and is modelled around the European Union's antitrust framework (Daudpota, 2019). However, while an appreciation of how far competition law has come in the country, it must be acknowledged that there is still a lot that needs to be done, especially with regard to digital platforms. The Pakistani competition law framework befits the traditional model of business. Competition law in Pakistan needs to be improved to better deal with the set of challenges presented by the emerging online economy, particularly with regard to the review and approval of mergers in the sector. In this regard, this paper takes a look at the merger review process in China which has a more mature competition law framework compared to Pakistan.

\section{Merger Control in China}

Mergers in the People Republic of China (PRC) are regulated by the Anti-Monopoly Law (AML) of 2008, particularly Chapter 4 (Articles 20 to 31) of the AML on "Concentra-tions between Undertakings" (Blewett \& Bal, 2018). The AML is supplemented by the 2008 Provisions of the State Council on notification thresholds for concentrations between un-dertakings, the Guiding Opinions on notifications of concentrations between undertakings, the Anti-Monopoly Commissions guidelines on the definition of relevant markets, the Measures for Review of concentrations, and the Interim Provisions on standards ap-plicable to simple cases of concentrations between undertakings (Jin, 2021). The merger control regime is enforced by the Anti-Monopoly Bureau of the State Administration for Market Regulation (SAMR) which replaced the Anti-Monopoly Bureau of the Ministry of Commerce (MOFCOM).

Parties to an intended merger are required to submit an anti-trust notification if the proposed transaction meets the turnover threshold and is deemed to be a concentration ("twin tests"). The turnover thresholds are triggered when each of the businesses intend-ing to merge have a revenue of RMB 400 million or higher derived within the PRC, or if the combined revenue in China is more than RMB 2 billion or the combined worldwide turn-over is above RMB 10 billion (Sokol, 2013). For the purposes of calculating the turnover thresholds, the total turnover of the relevant parties, undertakings directly or indirectly controlled by the parties, undertakings controlling the relevant party directly or indirectly, and undertakings that are jointly controlled by the relevant parties are considered (Sokol, 2013). The AML exempts certain types of transactions from merger review. These include transactions where one of the undertakings partaking in the concentration owns $50 \%$ or more of the assets or voting shares of the other undertaking or where one of the undertak-ings which is not a relevant party owns $50 \%$ or higher of the assets or voting shares of parties to the transaction (Sokol, 2013).

The Chinese antitrust law does not distinguish between domestic companies, foreign companies, private companies, or state-owned enterprises. Article 20 of the AML defines a concentration as to include (Zhu \& Zhu, 
2016); (a) mergers between undertakings, (b) ac-quisition of control of another undertaking through purchase of assets or shares, and (c) acquisition of control over another undertaking, or the acquisition of decisive influence over another undertaking through contract or other means. Although the concept of con-trol is not clearly defined in the AML, the 2014 Guiding Opinions on the Application for Concentration of Business Operators (Guiding Opinions) propose a test for decisive in-fluence based on factual and legal factors such as the articles of association of the target, shareholding structure of the target and post-merger changes, and purpose of the transac-tion (Zhu \& Zhu, 2016).

The Guiding Opinions under Article 3 prescribe that both factual and legal argu-ments should be applied to determine control. In this respect, control refers to the exercise of decisive influence over other businesses through transactions or other factors (Blewett \& Bal, 2018). Additionally, in establishing control or lack of it thereof, the bylaws of other business operators and concentration agreements are essential, but not the sole reference sources. When deciding whether a concern has control over other business, the factors to be considered include (Zhu \& Zhu, 2016) (i) reasons for the intended transaction (ii) cur-rent equity arrangement and resultant changes to the equity structure as a result of the transaction, (iii) shareholders' voting rights and mechanisms, (iv) Board structure and voting mechanism of the board of directors, (v) appointment and dismissal policies and procedures of senior management (vi) existence of a commercial cooperation between the controlling entity and the controlled entities.

Whereas China's AML is substantially modelled on the U.S. and E.U. competition policy structure, it nevertheless contains certain uncertainties and ambiguities on several antitrust issues, which significantly reflect Chinese economic and political concerns (Jin, 2021). For instance, Article 27 of the AML states that the factors that the SAMR can use in evaluating a merger are market share, degree of concentration, market power, effects on consumers and related undertakings, and the impact of market concentration on techno-logical innovation and market entry (Jin, 2021). However, it goes ahead to state that the ef-fect of the proposed transaction on national economic development should be considered as well as any other factor as determined by the SAMR (Jin, 2021). These additional regu-lations empower SAMR to impose conditions beyond the ambit of conventional antitrust economic factors.

The SAMR conducts a three-stage process when reviewing concentrations. The first phase is a preliminary review which must be completed within 30 calendar days (McKenzie, 2021). If the transaction does not give rise to antitrust concerns, the SAMR of-ten grants clearance within the 30-day preliminary review period after accepting the filing. However, before accepting the filing, the SAMR may take 30 to 60 days while undertaking an initial review (McKenzie, 2021). If the SAMR determines that the proposed merger raises antitrust concerns, the transaction is subjected to the second phase or "further re-view" which may take an additional 90 days. The 90day period can be extended by an-other 60 days in which the authority subjects the transaction to an "advanced review" (McKenzie, 2021).

The substantive tests applied by the SAMR in reviewing a transaction entail consid-ering whether the proposed transaction would restrict or eliminate competition (Zhu \& Zhu, 2016). Similar to the Pakistani merger control regime, a transaction may still be ap-proved if the filing party can prove the pro-competitive effects of the intended merger mit-igate its anti-competitive impacts. The transaction may also be approved if is deemed to enhance public interest. In the substantive review, the theory of harm as to the probability of the transaction restricting or eliminating competition is also taken into account (McKenzie, 2021). For horizontal mergers, the SAMR assesses coordinated and unilateral effects while for vertical mergers and conglomerates, the authority considers the upstream and downstream foreclosure effects in addition to the coordinated effects of the proposed merger (McKenzie, 2021).

Non-compliance with the Chinese antitrust laws such as violation of monopoly laws can lead to a fine of between one and 10 percent as may be determined by the an-ti-monopoly enforcement authorities (Zhu \& Zhu, 2016). The violators also bear civil lia-bility. Furthermore, failure to notify the SAMR of an intended transaction that meet the no-tification thresholds attracts a fine of not more than RMB 500,000, with the SAMR reserv-ing the power to order a reversal of any unauthorized transactions (Zhu \& Zhu, 2016).

In recent years, China has tightened its stance on digital platforms. Concerns over the rise of giant digital companies such as Alibaba, Ant Financial, Tencent, Taobao, JD.com, Tmall, Pinduoduo, and Xiaohongshu, and the economic power they have amassed have been at the center of the public policy debate in China (Baruzzi, 2021). Issues spanning from unfair competition, infringement, and monopolies in the platform economy have also come to the fore. To address the peculiarities of the platform economy, the Chinese gov-ernment has implemented regulations specifically for the digital market.

On February 7 2021, the SAMR implemented the Antitrust Guidelines for the Plat-form Economy (Platform 
Guidelines) with immediate effect and with the objective of curbing monopolistic behavior and promote the sustainable development of the Chinese digital economy (Baruzzi, 2021). The Platform Guidelines have, inter alia, banned mo-nopoly agreements which it describes as "agreements, decisions (written or oral), or other concerted actions taken by platform operators and operators to restrict or exclude compe-tition" (Baruzzi, 2021). According to the Platform Guidelines, monopoly agreements can be horizontal whereby parties agree to fix prices, restrict production or sales, segment the market, restrict new products or technologies, or boycott transactions through (a) using the platform to exchange or collect sensitive information such as information regarding sales or prices, (b) using data and algorithms for coordinated objectives, (c) using technical means to communicate, or (d) other means intended to achieve synergies (McKenzie, 2021). Monopoly agreements can also be vertical whereby parties (a) use technical means to set prices automatically, (b) use data and algorithms to limit prices directly or indirect-ly, (c) use the rules of the platform to unify prices, or (d) use platform rules, algorithms, or technical means to exclude or limit market competition (McKenzie, 2021). The evaluation of whether anti-monopoly agreements have been reached or not, the SAMR will take into account a range of factors including but not limited to the platform's market power, extent of hindrance of a particular platform to entrants into the relevant market, the competition conditions of the relevant market, and whether the agreement restricts or inhibits competi-tion (Baruzzi, 2021).

The platform guidelines also prohibit "hub and spoke" agreements (McKenzie, 2021). Hub and spoke agreements are horizontal restrictions generated by a supplier and im-plemented through players that are vertically related. Players in the digital economy can reach hub and spoke agreements by using data, algorithms, platform rules, or technologi-cal means to exclude or restrict competition among digital market operators (McKenzie, 2021).

The guidelines also recognize that operators in digital markets can abuse their dom-inant position in a plethora of ways such as selling goods at prices that are below cost to eliminate other players, refusing to transact with counterparties or restricting transactions with counterparties, treating counterparties unequally, or implementing tie-in sales with the goal of setting unreasonable trading conditions (McKenzie, 2021). Such practices are common, not only in the Chinese online economy, but in other jurisdictions as well. For example, it is not unusual for ecommerce platforms to prohibit sellers from selling on the online shops of competing platforms. The new rules will rectify this kind of behavior by Chinese super-platforms. The guidelines have also brought variable interest entities (VIEs) under the scope of antitrust review, which will henceforth be subject to filing requirements (Baruzzi, 2021). VIEs or agreement based control in China can be manipulated to circum-vent the requirements of the law when acquired by foreign investors to operate in the digi-tal economy.

More significantly, the platform guidelines have empowered the SAMR to conduct an ex officio assessment of non-notifiable tech deals that involve emerging platforms or start-ups, consequently failing to meet the turnover thresholds for notification (McKenzie, 2021). The SAMR may conduct an investigation if the if the revenues of a party to the con-centration fall below the threshold as a result of low or free pricing model. By introducing such transaction value thresholds, China joins the ranks of Germany and Austria which already have such laws in place to regulate mergers in the digital market. The guidelines have also stipulated new revenue calculation models for the digital economy which are different from the traditional industries for purposes of merger review (McKenzie, 2021). This is based on the realization that the platform economy is different in terms of business models, industry practices, and price charging methods. The guidelines state that reve-nues may be calculated from the service fee charged by the platform and other revenues generated by the platform for operators who only provide information matching services and earn service fees or commissions (McKenzie, 2021). The revenues being captured may also include transaction amounts involved in the platform if the platform takes a lead in the market or participates on only one side of the market (McKenzie, 2021).

With the overhaul in the antitrust enforcement framework for digital platforms, Chi-na has set the bar for other developing countries with a growing digital market to emulate. In light of the rapidly developing online economy in Pakistan, the government should also lead the process of enacting relevant legislation that captures the needs of the Pakistani digital market.

\section{Research Questions and Methodology}

The literature linking Pakistani's and China's antitrust regimes is indeed scarce. There lacks a thorough comparative analysis of both systems. The purpose of this disser-tation is to fill this existing gap. However, the concern of this research is to investigate the differences between China's antitrust regime and Pakistan's competition law in relation to merger control in the digital sector by answering the following research questions:

1) What are the differences between China's and Pakistani's antitrust regimes with regard to merger control for online platforms.

2) 2) Is China's merger control system better suited to deal with the digital economy than Pakistani's? 
3) Comparative legal analysis is not new to competition policy. The goal of comparative research in competition law is to investigate the differences and similarities between two antitrust regimes and find explanations. This enhances knowledge and understanding of the legal systems which serves as a basis for making recommendations for improvement, and possibly harmonization.

4) In conducting the comparative analysis, the researcher used the survey method. A purposive sample of three experts on competition policy in Pakistan were selected. Ac-cording to Ritchtie et al. (2013), purposive sampling is useful as it helps in selecting a demonstrative population. As opposed to random sampling, where the data to be ob-tained is more generalized, purposive sampling facilitates the selection of participants who are experienced with the topic of study. Primary data was collected through semistructured face-to-face interviews with the participants following a standard set of questions.

\section{Expert Interviews}

The purposive sample derived by the researcher comprised two scholars from Zhengzhou University School of Law and Economics and one former member of the Competition Commission of Pakistan. The researcher believes that the sample chosen is sufficiently knowledgeable of the competition law landscape in both China and Pakistan, particularly in relation to merger control for the platform economy. Although the interviews were semi-structured, adequate room was given to the respondents to express their opinions freely and elaborate on areas of special interest. Each interview lasted approximately one and a half hours

\section{Results and Discussion}

There is a general agreement among experts that China's competition law policy is more developed than Pakistani's and better suited to the cope with the dynamics of the digital economy. The first expert pointed out that although Pakistan has taken significant steps towards modernizing its competition law regime, a lot still remains to be done. M\&A ac-tivity in Pakistani's online sector are few compared to China, a phenomenon which can explain why the Chinese government has taken action to regulate digital platforms. The second expert noted that China has several super platforms, some of which have been in-volved in anti-competitive practices such as abuse of dominance and monopolistic be-havior. This has necessitated China to tighten its grip in digital market regulation. Further, the expert posited Pakistan currently utilizes traditional antitrust tools to review mergers occurring in the digital economy, giving an example of the Uber/Careem merger. The third expert concurred with the first two respondents indicating that China's competition poli-cy and merger control regime is more enhanced than Pakistan's. The expert pointed to the recently implemented antitrust guidelines for the online economy in China, equally agreeing that Pakistan should follow suit.

\section{Policy Implications for Pakistan}

While advanced economies such as the U.S., Germany, Britain, and Austria have taken a lead in regulating digital markets, the realization of the need to exercise control over the digital markets is gradually dawning on developing countries such as China and Paki-stan. In Pakistan, concerns have started to mushroom over the conduct of digital plat-forms, particularly with regard to M\&A activity. In the last few years, several Pakistani companies in the online sector have been acquired by large U.S. and Chinese digital com-panies. As activities in the Pakistani online sector intensify, more acquisitions in the digi-tal sector are likely to be witnessed in the coming years.

This study has determined that in terms of the responsiveness of antitrust policies to mergers in the digital economy, China is more advanced than Pakistan. Given that Chi-na's digital sector is far more advanced than Pakistan's, it is no surprise that the Pakistan is trailing with regard to antitrust enforcement in the sector. However, Pakistan's online innovation space is growing rapidly, attracting millions of dollars in investments and acquisitions every year. As such, it is high time that Pakistan revises its anti-trust policies to cope with the peculiarities of online platforms.

Price analysis and consumer welfare model which have been traditionally applied by the CCP to assess the anticompetitive effects of mergers and acquisitions do not reflect may not be sufficient for online platforms. The platforms exhibit significant network effects, and interconnected demand and pricing and, therefore, both sides should be included in defining the relevant market. While the CCP can use the SSNIP test, care should be taken to ensure that it does not result in a too broad or too narrow definition of the market. The CCP also needs to be cognizant of the zero pricing model of digital platforms which ren-der the SSNIP test less helpful in establishing whether products are competing. Moreover, as described in this paper, digital mergers often entail the acquisition of young start-ups by established tech companies. The transactions do not usually meet the legal notification thresholds and are, therefore, not subject to merger review. To net mergers in the digital sector that would have otherwise not been subject to evaluation, the CCP could assess transactions on a case-by-case basis. 
In conclusion, the merger control regime is sufficiently capable of assessment of mergers in the traditional economy, but is not adequately equipped to evaluate mergers and acqui-sitions in the digital sector. While the adoption of drastic measures such as the imple-mentation of new guidelines as has happened in China is a most ultimate step towards regulating the digital platforms, the existing traditional antitrust tools can address these challenges if appropriately modified. For a developing country such as Pakistan with a myriad of pressing economic and social development issues, the current legal framework need not be overhauled. Developing analytic tools within the current framework including transaction value thresholds and dealing with mergers on a case-by-case basis would still be sufficient to address the competition law challenges of the digital economy.

\section{References}

Argentesi, E., Buccirossi, P., Calvano, E., Duso, T., Marrazzo, A., \& Nava, S. (2020, March 4). Mergers and Merger Policy in Digital Markets. VOX, CEPR Policy Portal. Retrieved from https://voxeu.org/article/mergers-and-merger-policy-digital-markets

Atanasian, A. G. (2018). Digital Economy and Competition Policy. Russian competition law and economy, 18(1), 36-41. https://doi.org/10.32686/2542-0259-2018-1-36-41

Baruzzi, S. (2021, February 19). China Enforces Antitrust Guidelines on its Online Economy. China Briefing News. Retrieved from https:/www.china-briefing.com/news/china-antitrust-guidelines-enforcement-onlineeconomy/

Blewett, R., \& Bal, Y. (2018, August 31). Merger Control in China: A Practical Guide. Clifford Chance | International Law Firm | Global Law Experts. Retrieved from www.practicallaw.com/w-004-7032

Chirita, A. D. (2019). Data-Driven Mergers under EU Competition Law. The Future of Commercial Law. https://doi.org/10.5040/9781509914722.ch-007

Choi, Y. S., \& Youn, S. Y. (2013). The Enforcement of Merger Control in China: A Critical Analysis of Current Decisions by MOFCOM. IIC - International Review of Intellectual Property and Competition Law, 44(8), 948-972. https://doi.org/10.1007/s40319-013-0128-0

Competition Commission of Pakistan. (2016). Competition (Merger Control) Regulations, 2016. Retrieved from Competi-tion Commission of Pakistan website: http://www.cc.gov.pk

Crémer, J., De Montjoye, Y., \& Schweitzer, H. (2019). Competition Policy for the Digital Era (B-1049). European Commis-sion. Retrieved from https://ec.europa.eu/competition/publications/reports/kd0419345enn.pdf

Daudpota, F. (2019). Understanding Pakistan's merger control law. SSRN Electronic Journal, 1-6. https://doi.org/10.2139/ssrn.3473878

Dessemond, E. G. (2020). Restoring Competition in Winner-Took-All"Digital Platform Markets. UNCTAD. Retrieved from https://unctad.org/news/restoring-competition-winner-took-all-digital-platform-markets

Federal Ministry for Economic Affairs and Energy. (2019). A New Competition Framework for the Digital Economy. BMWi. Retrieved from www.bmwi.de/Redaktion/EN/Publikationen/Wirtschaft/a-newcompetition-framework-for-the-digital-economy.pdf

Gal, M. S., \& Cheng, T. K. (2016). Aggregate concentration: An Empirical Study of Competition Law Solutions. Journal of Antitrust Enforcement, 4(2), 282-322. https://doi.org/10.1093/jaenfo/jnw004

Jamal, M. (2013). The Merger Control Review: Pakistan (4th ed.). Law Business Research Ltd. Retrieved from www.mjlalegal.com/uploads/1/7/8/7/17874169/merger_control_review_-_pakistan_-_2013.pdf

Jin, Y. (2021, February 1). Merger Control Comparative Guide - China. Welcome to Mondaq. Retrieved from https://www.mondaq.com/china/anti-trustcompetition-law/856668/merger-control-comparative-guide

Karachi Chamber of Commerce and Industry (KCCI). (2021, February 10). Pakistan Launches Growth Funds for Startups. Karachi Chamber of Commerce \& Industry. Retrieved from https://www.kcci.com.pk/research/pakistan-launches-growth-funds-for-startups/

Khan, M. (2021, April 19). Valuing - and Overvaluing - Startups. dawn.com. Retrieved from https://www.dawn.com/news/1618946/valuing-and-overvaluing-startups

Khan, M., Khan, S. U., \& Rizwan, M. F. (2017). Analysis of Merger and Acquisition in Pakistan. NICE Research Journal, 24-44. https://doi.org/10.51239/nrjss.v0i0.16

Kundi, G. M. (2008). Digital Pakistan: Opportunities \& challenges. JISTEM Journal of Information Systems and Technology Management, 5(2), 365-390. https://doi.org/10.4301/s1807-17752008000200009 
Lilani, Z. (2021, January 3). The most well-funded tech startups in Pakistan. Medium. Retrieved from https://techshaw.com/the-most-well-funded-tech-startups-in-pakistan-8e09473620ef

Lundqvist, B. (2019). Regulating Competition in the Digital Economy. Competition Law for the Digital Economy, 2-28. https://doi.org/10.4337/9781788971836.00009

Maher, M., Reynolds, P., Muysert, P., \& Wandschneider, F. (2016). Resetting Competition Policy Frameworks for the Digital Ecosystem. GSMA. Retrieved from https://www.gsma.com/publicpolicy/wpcontent/uploads/2016/10/GSMA_Resetting-Competition_Report_Oct-2016_60pp_WEBv2.pdf

McKenzie, B. (2021, February 11). China: China Issues Anti-Monopoly Guidelines for the Internet Platform Economy. Lex-ology. Retrieved from https://www.lexology.com/library/detail.aspx?g=6faa5baf-8e9f-4bd889e5-9b606a2a269a

McKenzie, R. B., \& Lee, D. R. (2011). How Digital Economics Revises Antitrust Thinking. The Antitrust Bulletin, 46(2), 253-298. https://doi.org/10.1177/0003603x0104600202

Newman, J. (2018). Vanderbilt Law Review. Antitrust in Digital Markets, 72(5), 1497-1561. Retrieved from https://cdn.vanderbilt.edu/vu-wp0/wp-content/uploads/sites/278/2019/10/11172710/Antitrust-in-DigitalMarkets-1.pdf

Nicola, S. (2018, May 8). Alibaba Buys Online Retailer Daraz in Pakistan Push. Bloomberg. Retrieved from https://www.bloomberg.com/news/articles/2018-05-08/alibaba-buys-rocket-s-online-retailer-daraz-inpakistan-push

OECD. (2016). New Forms of Work in the Digital Economy (JT03398022). Retrieved from https://www.oecd.org/officialdocuments/publicdisplaydocumentpdf/

Partington, M. (2020, January 29). Pakistan: The Next Big Asian market for Tech Startups? dw.com. Retrieved from https://www.dw.com/en/pakistan-the-next-big-asian-market-for-tech-startups/a-52183841

Ritchie, J., Lewis, J., Nicholls, C. M., \& Ormston, R. (Eds.). (2013). Qualitative Research Practice: A guide for Social Science Students and Researchers. Thousand Oaks, CA: Sage.

Robinson, J. (2020). Pakistan: Progressing Towards a Fully fledged Digital Economy. GSMA. Retrieved from www.gsma.com/asia-pacific/wp-content/uploads/2020/06/24253-Pakistan-report-updates-LR.pdf

Sokol, D. D. (2013). Merger control under China's anti-monopoly law. New York University Journal of Law and Business, 10(1), 1-36. Retrieved from core.ac.uk/download/pdf/216975885.pdf

The Competition Act. (2010). Act of Majlis-e-Shoora (Parliament) No.F.22(30)/2009-Legis.

Uber. (2020, January 3). Uber Completes Acquisition of Careem. Uber Newsroom. Retrieved from https://www.uber.com/en-JO/newsroom/uber-careem-close-jo/

United Nations Conference on Trade and Development (UNCTAD). (2019). Competition issues in the digital economy [Pa-per presentation]. 18th session of Intergovernmental Group of Experts on Competition Law and Policy. Retrieved from https://unctad.org/en/Pages/MeetingDetails.aspx?meetingid=1895

United Nations Conference on Trade and Development (UNCTAD). (2020, October). Strengthening Consumer Protection and Competition in the Digital Economy [Paper presentation]. Eighth United Nations Conference to Review All Aspects of the Set of Multilaterally Agreed Equitable Principles and Rules for the Control of Restrictive Business Practices, Geneva. Retrieved from https://unctad.org/system/files/officialdocument/tdrbpconf9d4_en.pdf

United Nations Conference on Trade and Development. (2013). Voluntary Peer Review on Competition Law and Policy (UNCTAD/DITC/CLP/2013/4). UNCTAD. Retrieved from unctad.org/system/files/officialdocument/ditcclp2013d4_en.pdf

Wilson, J. (2011). Crossing the Crossroads: Making Competition Law Effective in Pakistan. Loyola University Chicago In-ternational Law Review, 8(2), 105-125. Retrieved from https://lawecommons.luc.edu/lucilr/vol8/iss $2 / 2$

Wirth, D., \& Parr, N. (2020, August 12). Merger control 2021: Reform or revolution? The Approach to Assessing Digital Mergers. International Comparative Legal Guides International Business Reports. Retrieved from https:/iclg.com/practice-areas/merger-control-laws-and-regulations/reform-or-revolution-the-approach-toassessing-digital-mergers

World Economic Forum (WEF). (2019). Competition Policy in a Globalized, Digitalized Economy. WEF. 
Retrieved

from

http://www3.weforum.org/docs/WEF_Competition_Policy_in_a_Globalized_Digitalized_Economy_Report .pdf

Y.W. Tang, R., \& M. Metwalli, A. (2013). Mergers and acquisitions in India, Pakistan and Bangladesh. International Journal of Commerce and Management, 23(4), 327-338. https://doi.org/10.1108/ijcoma-042013-0039

Yüksel, B., Kurt, A., \& Aydinli, C. D. (2020, January 17). The Beginning of the New Challenge: Merger Control in Digital Economy - Anti-Trust/Competition Law. Mondaq. Retrieved from https://www.mondaq.com/turkey/AntitrustCompetition-Law/884564/The-Beginning-Of-The-NewChallenge-Merger-Control-In-Digital-Economy

Zhu, H., \& Zhu, Q. (2016). Mergers and acquisitions by Chinese firms: A review and comparison with other mergers and acquisitions research in the leading journals. Asia Pacific Journal of Management, 33(4), 11071149. https://doi.org/10.1007/s10490-016-9465-0

\section{Copyrights}

Copyright for this article is retained by the author(s), with first publication rights granted to the journal.

This is an open-access article distributed under the terms and conditions of the Creative Commons Attribution license (http://creativecommons.org/licenses/by/4.0/). 